\title{
Effect of Repetitive Transcranial Magnetic Stimulation Combined with Exercise Therapy on the Motor Function in Stroke Patients with Hemiplegia
}

\author{
ZHOU Wani ${ }^{1}$, ZHANG Lei ${ }^{1}$, LI Rundong ${ }^{1}$, XU Kaiquan ${ }^{1 *}$, WU Chengji ${ }^{2}$ \\ ${ }^{1}$ Qingdao Haici Medical Group, Qingdao, Shandong 266033, China; \\ ${ }^{2}$ The First Affiliated Hospital of Jiamusi University, Jiamusi, Heilongjiang 150001, China \\ * Correspondence: XU Kaiquan. E-mail: 517795782@qq.com
}

\begin{abstract}
Objective: To discuss the effect of repetitive transcranial magnetic stimulation (rTMS) combined with exercise therapy on the motor function in stroke patients with hemiplegia. Methods: A total of 100 stroke patients with hemiplegia were selected from September 2016 to September 2018, according to the random number table, and they were divided into excitation group and exercise group, with 50 cases in each group. The exercise group was treated with exercise therapy, and the excitation group was treated with rTMS combined with exercise therapy. Before treatment and after 3 months' treatment in the two groups, the latency of motor evoked potential (MEP) and central motor conduction time (CMCT) were measured by magnetic transcranial therapy, the motor function of upper and lower limbs were detected by Fugl-Meyer assessment scale (FMA), the quality of life were detected by activity of daily living scale (ADL), and the electrophysiological indexes, motor function, quality of life of the two groups were compared. Results: There was no significant difference in MEP $[(26.58 \pm 3.01) \mathrm{ms}$ and $(26.34 \pm 2.97) \mathrm{ms}]$, CMCT $[(12.80 \pm 1.58) \mathrm{ms}$ and $(12.75 \pm 1.56) \mathrm{ms}]$ between the excitation group and the exercise group before treatment $(P>0.05)$. The MEP $[(20.15 \pm 2.26) \mathrm{ms}$ and $(23.24 \pm 2.56) \mathrm{ms}]$ and CMCT $[(10.04 \pm 1.26) \mathrm{ms}$ and $(11.64 \pm 1.24) \mathrm{ms}]$ in the excitation group and the exercise group after three months' treatment were significantly lower than those before treatment, the MEP and CMCT in the excitation group after three months' treatment were significantly lower than those in the exercise group, the difference was statistically significant $(P<0.001)$. There was no significant difference in FMA scores of upper limbs [(22.24 \pm 2.66$)$ scores and $(22.46 \pm 2.72)$ scores $]$, FMA scores of lower limbs [(10.31 \pm 1.66$)$ scores and $(10.23 \pm 1.62)$ scores $]$ between the excitation group and the exercise group before treatment $(P>0.05)$. The FMA scores of upper limbs $[(40.25 \pm 4.23)$ scores and $(34.58 \pm 3.95)$ scores $]$ and lower limbs $[(19.36 \pm 2.21)$ scores and $(15.26 \pm 1.92)$ scores $]$ in the excitation group and the exercise group after three months' treatment were significantly higher than those before treatment. After three months' treatment, FMA scores of upper limbs and lower limbs in the excitation group were significantly higher than those in the exercise group, with statistically significant differences $(P<0.001)$. There was no significant difference in ADL scores $[(40.91 \pm 4.82)$ and $(40.56 \pm 4.62)]$ between the exercise group and the exercise group before treatment $(P>0.05)$. The ADL scores $[(67.56 \pm 7.02)$ scores and $(59.72 \pm 6.52)$ scores $]$ in the exercise group and the exercise group after three months' treatment were significantly higher than those before treatment, and the ADL scores in the excitation group after three months' treatment were higher than those in the exercise group, with statistically significant difference $(P<0.001)$. Conclusions: rTMS combined with exercise therapy can effectively improve the motor neuroelectrophysiological indexes and motor function of stroke patients with hemiplegia, which is conducive to improving the quality of patients' life and worthy of clinical promotion.
\end{abstract}

KEY WORDS stroke; hemiplegia; repetitive transcranial magnetic stimulation; exercise therapy; motor function

DOI: $10.3724 /$ SP.J.1329.2020.03013

•好书推荐.

\section{《骨科康复评定与治疗技术》(第 5 版) 出版}

26 年再版 5 次! 中山大学孙逸仙纪念医院康复医学科燕铁斌教授主编的《骨科康复评定与治疗技术》 (第 5 版) 由科学出版社出版。该书自 1994 年首版以来再版 5 次, 第 5 版继续保持实用、指导性强的特点。全 书分 4 篇 20 章: 骨科康复基础篇、骨科康复评定方法篇、骨科康复治疗技术篇、骨科 疾患康复临床应用篇,配以大量插图, 突出了实用性和可读性。适用于从事骨科康 复的医护人员,可作为康复治疗技术培训用书、医学院校康复治疗专业师生教学 参考等。

为了让读者以最优惠价格购买到正版,经与出版社联系, 采取团购,欢迎扫描下 列二维码咨皅。原价: 229 元/本,团购价: 170 元/本(包邮), 20 本以上可开发票。联 系人:李老师 (加微信时备注“购书”), 联系电话: 020-81332880。

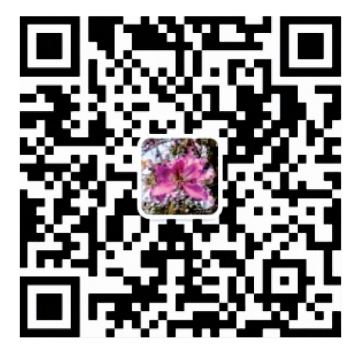

